\title{
Acclimatization to chronic intermittent hypoxia in mine workers: a challenge to mountain medicine in Chile
} \author{
Pulgar $3,4, \dagger$ \\ 1 Departamento de Ingeniería Química y Ciencias, Facultad de Ingeniería, Universidad de La Frontera, Temuco, Chile. \\ ${ }^{2}$ Medicina de Altura Ltda. Santiago, Chile. \\ ${ }^{3}$ Biomedical Research Infrastructure Center, Winston-Salem State University, Winston Salem, NC, USA. \\ ${ }^{4}$ Department of Obstetrics and Gynecology, Wake Forest School of Medicine, Winston Salem, NC, USA. \\ * These authors contributed equally to this work.
}

Jorge G. Farías ${ }^{1,},{ }^{*}$, Daniel Jimenez ${ }^{2}{ }^{*}$, Jorge Osorio $^{2}$, Andrea B. Zepeda ${ }^{1}$, Carolina A. Figueroa ${ }^{1}$ and Victor M.

\begin{abstract}
In the past two decades, Chile has developed intense mining activity in the Andes mountain range, whose altitude is over 4,000 meters above sea level. It is estimated that a workforce population of over 55,000 is exposed to high altitude hypobaric hypoxia. The miners work under shift systems which vary from 4 to 20 days at the worksite followed by rest days at sea level, in a cycle repeated for several years. This Chronic Intermittent Hypoxia (CIH) constitutes an unusual condition for workers involving a series of changes at the physiological, cellular and molecular levels attempting to compensate for the decrease in the environmental partial pressure of oxygen $\left(\mathrm{PO}_{2}\right)$. The mine worker must become acclimatized to $\mathrm{CIH}$, and consequently undergoes an acute acclimatization process when he reaches the worksite and an acute reverse process when he reaches sea level. We have observed that after a period of 3 to 8 years of CIH exposure workers acclimatize well, and evidence from our studies and those of others indicates that $\mathrm{CIH}$ induces acute and chronic multisystem adjustments which are effective in offsetting the reduced availability of oxygen at high altitudes. The aims of this review are to summarize findings of the physiological responses to $\mathrm{CIH}$ exposure, highlighting outstanding issues in the field.
\end{abstract}

Key words: High Altitude, Mine Workers, Intermittent Hypoxia, Acclimatization, Chilean Model.

\section{GENERAL CONCEPTS}

High altitude-induced hypobaric hypoxia involves a series of adaptive changes in multiple physiological systems in exposed individuals. Based in our findings and those of others, in this review we summarize the main physiological responses observed in mine workers intermittently exposed to hypobaric hypoxia. The literature on the occupational health of high-altitude exposed workers has been recently reviewed by Vearrier and Greenberg, 2011.

Hypobaric hypoxia occurs as a consequence of the low partial pressure of oxygen $\left(\mathrm{PO}_{2}\right)$ in the inspired air, resulting from the low barometric pressure found at high altitudes. A lower arterial $\mathrm{PO}_{2}$ in turn initiates a physiological response attempting to maintain tissue oxygenation. One parameter used to determine respiratory response and the transport of oxygen in the blood to the tissues is percent hemoglobin saturation $\left(\% \mathrm{SaO}_{2}\right)$, which can be estimated with a portable device. At sea level values fluctuate between 95 and 97\%; values below $90 \% \mathrm{SaO}_{2}$ are associated with pathological situations such as respiratory failure (Farias et al., 2006). An effect produced by exposure to hypobaric hypoxia is the well known Acute Mountain Sickness (AMS), whose symptoms include headaches, vomiting, fatigue, loss of appetite and sleep disturbances (Hackett et al., 1976, León-Velarde et al., 2010).

The acute response to hypoxia depends mainly on 4 factors: a) the altitude reached, i.e. the degree of hypobaric hypoxia, b) the rate of climb, c) individual susceptibility, and d) physical and environmental requirements in the ascent and arrival. It is known that upon exposure to $2,500 \mathrm{~m}$ altitude the problems associated with hypobaric hypoxia begin, with the consequent challenges for the individuals exposed (León-Velarde et al., 2005).

The lower availability of oxygen at high altitudes triggers physiological mechanisms that first seek to protect oxygen transport to the tissues, inducing mainly respiratory and cardiovascular adjustments. The increase in ventilation depends on the activity of the peripheral chemo receptors, particularly those located inside the carotid bodies that detect changes in arterial $\mathrm{PO}_{2}$ and transmit sensorial information to regulate breathing (Prabhakar et al., 2000). Some data indicate that enzymes present in all mammalian cells, especially hydroxylases, are sensitive to moderate hypoxia and their activity may be controlled at several other levels, which provides flexibility to the physiological responses to hypoxia (Schofield and Ratcliff, 2004).

Important factors in personal susceptibility to hypoxia are the presence of sensitive oxygen sensors and effective physiological adaptations. Based on susceptibility to hypoxia, exposed individuals may be classified as good responders, who tolerate and acclimate without symptoms; a group with a low response and temporary minor symptoms that may limit performance; and poor responders, who display low sensitivity to hypoxia and ineffective compensatory physiological responses.

Residency in high altitude locations exposes humans to ambient hypobaric hypoxia, thus Chronic Hypoxia exposure 
refers to groups of people who live for generations at high altitudes or are occasionally exposed to short periods (days) of normoxia. Acute Hypoxia refers to individuals who live at sea level and are exposed to high altitudes for only minutes, hours or days, as in the case of mountain climbers. Periodic intermittent exposure to high altitudes, as in the case of the Chilean miners who work at altitudes over $4,000 \mathrm{~m}$ is called Chronic Intermittent Hypoxia (CIH) (Richalet et al., 2002; Vargas et al, 1989; Farías et al., 2006). Mining workers at high altitudes must adjust to the requirements of hypobaric hypoxia for some days and then return to sea level, where they lose some of the acclimatization to hypoxia, depending on the time in normoxia. This model of exposure to hypobaric hypoxia, named the Chilean model or $\mathrm{CIH}$ exposure, has received increased attention in recent years (Casanegra et al., 1993; Chamorro et al., 1993; Jalil et al., 1994; Jimenez 1995; Richalet et al., 2002; Farias et al., 2006; Brito et al., 2007).

\section{ACCLIMATIZATION TO INTERMITTENT EXPOSURE TO HIGH ALTITUDES}

The term 'altitude acclimatization' describes the processes whereby lowland humans and animals respond to reduced $\mathrm{PO}_{2}$ in the inspired air. It refers only to the changes in response to hypoxia seen as beneficial, as opposed to changes that are pathological and result in illness such as AMS (West et al., 2007; Vearrier and Greenberg, 2011). Altitude acclimatization involves a series of adaptive physiological adjustments that compensate for the reduction in ambient $\mathrm{PO}_{2}$ (see Figure 1) and is the best strategy for the prevention of AMS (Forgey,
2006) Altitude acclimatization allows people to achieve their maximum physical and cognitive work performance possible for the altitude once they are acclimatized (Fulco et al., 2000).

\section{1.. Physiological effects of intermittent hypobaric hypoxia.}

Cyclical exposure to high altitude triggers responses throughout the route of oxygen, beginning with the carotid chemoreceptors and including ventilatory responses, pulmonary circulatory adjustments, the alveolar/capillary barrier, erythropoietin, hemoglobin, adjustments in the distribution of intra and extravascular fluid, changes in acidbase conditions, $\mathrm{PO}_{2}, \mathrm{PCO}_{2}$ and $\mathrm{O}_{2}$ delivery at the cellular level, with modifications in the peripheral capillaries and mitochondrial enzyme optimization.

One type of intermittent exposure to hypobaric hypoxia occurs with exercise training at high altitude; endurance athletes have evolved different models of exposure with the ultimate goal of increasing athletic performance at sea level. The most used models are Live High (at altitude) and Training Low (at sea level) LH-TL, Live High-Train High LH$\mathrm{TH}$, Intermittent Hypoxic Exposure (IHE) and Intermittent Hypoxic Training (IHT) (Wilber, 2007). With the aim of using altitude acclimatization to enhance aerobic capacity via hypoxia-induced increases in serum erythropoietin and hemoglobin concentrations, athletes either live and/or sleep in hypoxia (natural or artificial). Also, by stimulating ventilation and better oxygen saturation, the increased aerobic capacity improves muscle oxygenation and increases exercise tolerance. Based on studies of maximum oxygen uptake $\left(\mathrm{VO}_{2} \mathrm{max}\right)$ and

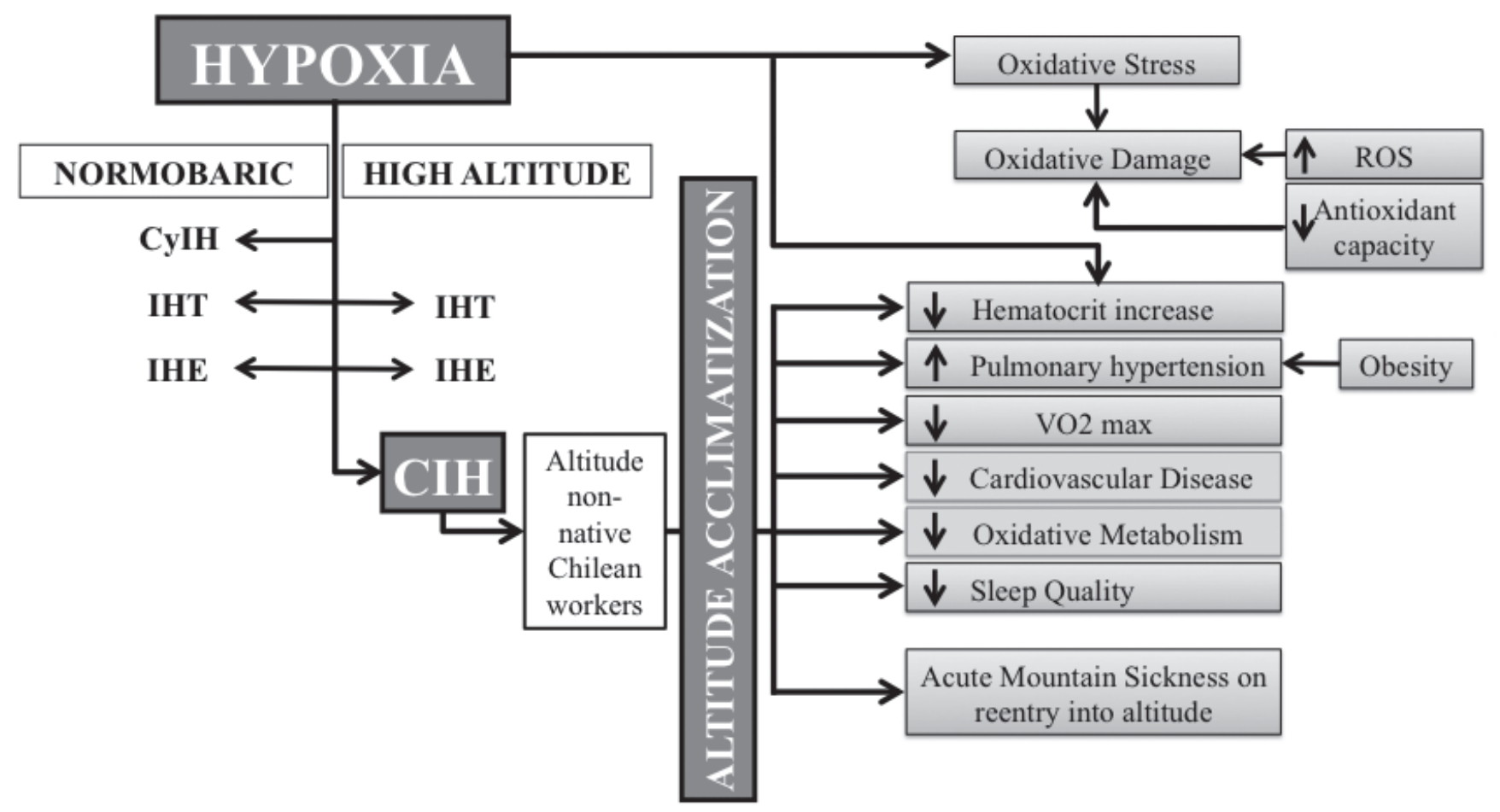

Figure 1. Physiological responses to hypoxia and effects of high altitude acclimatization. CylH: Cyclic Intermittent Hypoxia. IHT: Intermittent Hypoxic Training. IHE: Intermittent Hypoxic Exposure. CIH: Chronic Intermittent Hypoxia. ROS: Reactive Oxygen Species. See text for details. 
(maximum) power output, training at high altitude does not consistently result in increased exercise performance at sea level, with some evidence indicating benefits of training at high altitude on exercise performance at altitude (Vogt and Hoppeler, 2010). A great individual variability in responses has been observed and although some debate still exists in terms of the efficacy of the different models, combinations of them are being recently explored to improve results (see Millet et al., 2010 for review). From a research standpoint this experience has served to learn more about how hematological, aerobic and muscle responses are modulated by intermittent hypoxia (de Paula and Niebauer, 2012).

Other forms of intermittent exposure to hypoxia occur in several diseases such as chronic obstructive pulmonary disease, congestive heart failure, obesity-hypoventilation syndrome and obstructive sleep apnea, where hypoxia and normoxia occur at the same barometric pressure. This intermittent isobaric hypoxia is called recurrent or cyclic intermittent hypoxia (CyIH) (Gilmartin et al., 2008). The study of the relationships between $\mathrm{CyIH}$ and cardiovascular disease has seen significant progress; however the physiological mechanisms linking them remain unknown. Both animal (Fletcher et al., 1992; Brooks et al., 1997) and human (Peppard et al., 2002) models showed increases in arterial blood pressure after $\mathrm{CIH}$ exposure with enhanced chemosensitivity being invoked as a contributor to the CIH-induced increased blood pressure (Tamisier et al., 2009).

$\mathrm{CIH}$ exposure in no altitude native Chilean miners differs from the IHT/IHE and CyIH because it involves alternating between normobaric normoxia and hypobaric hypoxia. The $\mathrm{CIH}$ model has gathered interesting information about the characteristics of acclimatization to $\mathrm{CIH}$, particularly in relation to the effects of hypoxia, but there is also evidence that hypobaria is playing a role. For example, studies showing different heart rate variability responses in normobaric hypoxia versus hypobaric hypoxia suggest that these two exposure conditions are clearly not equal stimuli to the cardiovascular and respiratory systems (Basualto-Alarcón et al., 2012).

The long term adjustments in $\mathrm{CIH}$ tend to resemble those in chronic hypoxia at the level of ventilatory and cardiovascular responses, red cell mass and cardiac $\beta$-adrenergic receptors, among others. Considering exposure to the same altitude however, there is a difference in the time needed to complete acclimatization. Whereas acclimatization to chronic hypoxia is achieved in few months, $\mathrm{CIH}$ acclimatization is achieved in years, with stabilization of biomedical variables being observed after 18 months of exposure (Richalet et al., 2002; Jimenez, 2003).

\subsection{Polycythemia and Pulmonary Hypertension}

Some of the body's first strategies when man or other animals not genetically adapted to high altitudes are subjected to hypoxia are expressed as metabolic, respiratory and cardiovascular adjustments. The increased production of red blood cells that improves oxygen transport capacity from the lungs to the tissues is one of them (Richalet, 1990). In the kidney, hypoxia stimulates the secretion of the hormone erythropoietin (after 2 to 3 hours of exposure to high altitude), which in turn stimulates the production of red blood cells by the bone marrow. This increase in erythropoiesis becomes the essential mechanism of long term acclimatization (Eckardt et al., 1989).

In a study performed in Chilean mine workers, Richalet et al., 2002 showed that hematocrit increased both at sea level and at high altitude after 12 and 19 months of $\mathrm{CIH}$, and returned to pre-exposure values after 31 months of $\mathrm{CIH}$ exposure. The risk of polycythemia was lower than in chronic highlanders (Richalet et al., 2002). In another study of subjects exposed to $\mathrm{CIH}$ for 12 years or more to a $4 \times 3$ commuting system ( 4 days at altitude and 3 days at sea level) at 3,550 $\mathrm{m}$ altitude, hematocrit and hemoglobin reached lower values than for residents at altitude over 4,000 $\mathrm{m}$ (Brito et al., 2007).

According to the Venice Symposium Consensus, pulmonary hypertension $(\mathrm{PH})$ is defined as a mean pulmonary artery pressure $(\mathrm{PAP})>25 \mathrm{~mm} \mathrm{Hg}$ in conjunction with right ventricle (RV) and right atrium (RA) enlargement (McLaughlin, 2004). PH is described as a marker of chronic exposure to high altitude-induced hypoxia; a direct relationship exists between PAP and the altitude reached (Peňaloza and Arias-Stella, 2007). The development of high-altitude $\mathrm{PH}$ is one of the main physiological changes observed in a poor response to hypoxia, and in people who permanently live at high altitudes the prevalence of $\mathrm{PH}$ increases from 5 to $10 \%$ (Leon-Velarde et al., 2005).

A 32-month prospective study performed in Chilean miners exposed to $\mathrm{CIH}$ in a $7 \times 7$ commuting system at $4,500 \mathrm{~m}$ a.s.l. showed that PAP increased in hypoxia, but further evidence of PH was not observed (Antezana et al., 2003). Moreover, values of PAP were lower than in subjects living permanently at high altitude (Richalet et al., 2002; Hultgren, 1997). Similar results were observed in a 24-month follow-up of workers exposed to $\mathrm{CIH}$ in a $28 \times 28$ commuting system at 3,700 $\mathrm{m}$ a.s.l. at Kumtor, Kyrgyzstan (Saryvaeb et al., 2003). However in subjects with more than 12 years of exposure to $\mathrm{CIH}$, a $4 \%$ prevalence of $\mathrm{PH}$ was observed (Brito et al., 2007). Thus polycythemia and $\mathrm{PH}$ are some of the main chronic changes during exposure to chronic hypoxia and $\mathrm{CIH}$ at high altitude (Pasha and Newman, 2010; Leon-Velarde et al., 2010; Brito et al., 2007).

Obesity, defined as a body mass index above $30 \mathrm{~kg} / \mathrm{m}^{2}$, has been reported to be a risk factor for the development of $\mathrm{PH}$ at high altitude, and obesity-related hypoventilation has been reported to be the primary mediator of the increased risk for this disorder (Valencia et al., 2004).

\subsection{Physiological response to Exercise}

Exercise tests are often used to elucidate the effects of high altitude hypoxia on aerobic capacity. We used two different protocols of exercise to test the degree of acclimatization and the response to exercise during high altitude induced-CIH. The response to sub-maximal exercise (workload of 100 watts in a stationary bike) was used as a test of acclimatization. In mine workers exposed to $\mathrm{CIH}$ in a $7 \times 7$ commuting system at 4,500 $\mathrm{m}$ for a period of 2.5 years, blood pressure, heart rate and artery oxygen saturation during resting and during exercise were measured. $\mathrm{CIH}$ resulted in a useful degree of acclimatization that was maintained over a period of three years (Farías et al., 2006). Conversely, another group of workers exposed intermittently to high altitudes showed that the cardiovascular response to a sub-maximal exercise load does not change between the first and fourth day of shifts at high altitudes (Jalil et al., 1994). In order to test long term effects of $\mathrm{CIH}$ exposure 
on exercise performance we used Aerobox sessions. Aerobox is a high-energy exercise regime that combines moves from a range of martial arts disciplines. Methodologically, the phases of a 45 min Aerobox training session are warm up, main phase (with the highest cardiovascular impact), localized phase (such as pushups and abdominal exercises) and recovery phase (this phase allows time for the blood vessels and the heart to resume their normal status).

Studies performed by Osorio in 2005 (unpublished) on 12 workers acclimatized to $\mathrm{CIH}$ performing Aerobox sessions at 4,000 $\mathrm{m}$ altitude indicated that the lowest level of oxygen saturation appears in the cardiovascular phase, with $83 \%$ $\mathrm{SaO}_{2}$ (Table 1). Heart rate (HR) reached a higher level in the cardiovascular phase with $159 \mathrm{bpm}$. Considering that the heart rate at maximum exercise (HRmax) for this group is 172 bpm (Astrand, 1952; Fox et al., 1971; Richalet et al., 2002), HR during the cardiovascular phase reached 92\%HRmax, a value considered adequate for training at maximum aerobic capacity (American College of Sports Medicine, 2000; Skinner et al., 2003). In the localized phase 59\% HRmax was observed, indicating that the cardiac rhythm is within the physiological limits recommended for aerobic training (American College of Sports Medicine, 2000); Skinner et al., 2003). The high level of HR observed during exercise corresponds to a group trained and acclimatized to high altitudes.

Richalet et al., (2002) found that maximum oxygen consumption $\left(\mathrm{VO}_{2} \max \right)$ decreased significantly with time of $\mathrm{CIH}$ exposure. Only part of this decrease can be attributed to the decrease in maximum heart rate induced by the downregulation of $\beta$-adrenergic and upregulation of muscarinic receptors (Richalet et al., 1992). A detraining effect of $\mathrm{CIH}$ exposure and/or sedentary living during the resting periods at sea level are probably also responsible for this effect (Richalet et al., 2002). A lack of physical activity during mining work could be another reason to explain the reduction in $\mathrm{VO}_{2}$ max.

\subsection{Cardiovascular response}

Andean mountain medicine has repeatedly shown that populations chronically exposed to altitude have low incidence of hypertension, atherosclerosis and myocardial infarction (Mortimer et al., 1977; Naeije, 2010). To what extent these characteristics depend on chronic hypoxia exposure, racial or nutritional factors has not yet been elucidated (Gamboa, 2003). Similarly, it has been recognized that long-term highaltitude hypoxia exposure protects the heart against ischemia / hypoxia injury, inducing a reduction of infarct size during acute ischemia. The relaxing effects of hypoxia on arterial smooth muscle cells may be proposed as contributors to this protection, as this vasodilatation tends to counteract polycythemia-induced blood viscosity (Hurtado, 1960).

Overall, the initial cardiovascular effects of altitude exposure involve an acute response associated with increased HR, blood pressure, cardiac output and myocardial contractility. Over time, during chronic hypoxia cardiac output decreases at levels lower than pre-exposure, accompanied by a decrease in sympathetic activity secondary to cardiac $\beta$-adrenergic receptor desensitization (Richalet, 1990).

Multiple mechanisms are involved in the cardioprotection induced by $\mathrm{CIH}$. Hypobaric $\mathrm{CIH}$ preserves myocardial contractility and prevents apoptosis of cardiomyocytes (Beguin et al., 2007, Zhu et al., 2006, Dong et al., 2003, Zhang et al., 2004), increases coronary flow and myocardial capillary angiogenesis, activates ATP-sensitive $\mathrm{K}^{+}$channels and inhibits mitochondrial permeability transition pores (Zhong et al., 2002, Zhu et al., 2003). A rat model of $\mathrm{CIH}$ has also provided evidence that $\mathrm{CIH}$ attenuates $\beta$-adrenergic receptor activity by decreasing $\beta$-adrenergic receptor density and affinity in the right ventricle, and these alterations in the $\beta$-adrenergic receptor may contribute to cardiac protection in CIH (Guan et al., 2010).

In miners exposed to $\mathrm{CIH}$ for 31 months, blood pressure initially increased followed by a reduction, but remained slightly elevated compared to blood pressure measured at sea level; also a reduction in pulse and a slight dilation of the right ventricle were observed (Richalet et al., 2002; Farias et al., 2006). A study performed on Chilean soldiers exposed to $\mathrm{CIH}$ for more than 12 years revealed an increase in the amount of triglycerides and a reduction in LDL cholesterol (Brito et al., 2007).

Autonomic control in high altitude-exposed subjects has been studied using the non-invasive technique of power spectral analysis of HR (heart rate variability; HRV). Variables usually determined included power in the low (LF, 0.04$.0 .15 \mathrm{~Hz})$ and high $(\mathrm{HF}, 0.15-0.4 \mathrm{~Hz})$ frequency ranges of the heart period spectrum, among others. Analyses showed an increase in the $\mathrm{LH} / \mathrm{HF}$ ratio during acclimatization (Sevre et al., 2001). Since HF power is assumed to be a marker of parasympathetic activity and LF power to be a combination of both parasympathetic and sympathetic tonic activity, it has been concluded that the sympathetic tone is less reduced than the parasympathetic control of HR upon high-altitude exposure (Sevre et al., 2001; Cornolo et al., 2004).

\subsection{Metabolic response and metabolic rate}

High altitude-induced hypoxia alters the regulation of substrate metabolism favoring carbohydrate oxidation,

TABLE 1

Hemoglobin saturation $\left(\mathrm{SaO}_{2}, \%\right)$ and heart rate $(\mathrm{HR}, \mathrm{bpm})$ values during Aerobox sessions at 4,000 m altitude in workers acclimatized to $\mathrm{CIH}$.

\begin{tabular}{cccccc} 
& & \multicolumn{4}{c}{ Aerobox Sessions (phases) } \\
\cline { 3 - 6 } & Resting & Warming up & Main & Localized & Recovery \\
\hline $\mathrm{SaO}_{2}, \%$ & $90 \pm 3$ & $89 \pm 2$ & $83 \pm 2$ & $90 \pm 6$ & $92 \pm 4$ \\
$\mathrm{HR}$, bpm & $83.5 \pm 4.3$ & $89.2 \pm 5.6$ & $159 \pm 10$ & $101 \pm 9.6$ & $90.6 \pm 8.8$ \\
\hline
\end{tabular}

(mean $\pm \mathrm{SD}, \mathrm{n}=12$ ) 
as an adaptive mechanism to the limited ATP supply due to a diminished oxidative phosphorylation caused by the reduction in the available oxygen. Thus cells increase anaerobic glycolysis through positive regulation of the glycolytic enzymes and decrease the activity of some ATP consumers, e.g., $\mathrm{Na}^{+}-\mathrm{K}^{+}$ATPase. Invariably acclimatization to high altitudes results in the increased use of blood sugar (Brooks et al., 1991). It has also been demonstrated that acclimatization to hypobaric hypoxia selectively reduces key enzymes responsible for lipid oxidation in heart, liver and skeletal muscle. Therefore, the greater dependency on blood sugar than on lipid metabolism probably contributes to the maintenance of homeostasis by optimizing the energy performance per unit of oxygen (Kennedy et al., 2001). We have studied the relationships between oxidative mitochondrial phosphorylation and oxygen consumption during chronic or intermittent hypobaric hypoxia exposure. Using a rat model of exposure to simulated conditions of continuous or intermittent high altitude (Farías et al. 2005a, Farías et al., 2005b) we observed a greater inhibition of oxygen consumption in spermatid cells in chronic versus intermittent hypobaric hypoxia (inhibition of $80 \%$ vs. 57\%, respectively), in the presence of the mitochondrial $\mathrm{H}^{+}$-ATPase inhibitor oligomycin. Similar oxygen consumption in both hypoxic treatments was observed after uncoupling of the oxidative phosphorylation, suggesting that continuous chronic hypobaric hypoxia is associated with an uncoupling of oxidative phosphorylation.

Basal metabolic rate (BMR) increases during the first days of exposure to high altitudes, apparently depending on the altitude reached. Increases of $6 \%$ and $10 \%$ have been found at altitudes of 3,650 and 3,800 m, respectively. As the days progress BMR decreases, but does not reach sea level values. For mountaineers who climb for 10 to 18 hours a day in high altitudes, the largest proportion of their energy comes from fats, and glycogen is only used for short and high-intensity exercises. However, after 18 days at the moderate altitude of 4,300 m, Young et al. (1982) found that the muscular glycogen at rest was lower than at sea level. Apparently, there are no data available about the deposits of muscular and hepatic glycogen at extreme altitudes, but with many more days of intensive work and adequate caloric consumption, it would not be surprising to find this reduced in liver and muscle (Young et al., 1982). These findings suggest that in humans from sea level chronically exposed to high altitudes, fat is the principal fuel for exercise and the re-synthesis of the muscular glycogen can be reduced. It is not clear whether this is an effect of altitude or lower food consumption during hypoxia exposure. An elevated metabolism in rats (Rennie et al., 1977) and humans (Costill et al., 1977) has also been observed, indicating a saving of muscular glycogen, probably through the inhibition of the enzymes phosphofructokinase and pyruvate dehydrogenase.

\subsection{Sleep quality}

Travel to altitude is associated with a reduction in sleep quality (Anholm et al., 1992). These symptoms can be relieved with descent, simulated descent in a hyperbaric chamber or by enhancing room air with oxygen (West, 2002). In addition, travel to altitude results in a temporary reduction of rapid eye movement (REM) sleep that appears to improve with acclimatization (Anholm et al., 1992; Przybylowski et al., 2003). In the study performed by Richalet et al., (2002) with
Chilean miners, sleep quality was altered during the first two nights at high altitude (worse on the second night) and did not ameliorate with time of exposure. In workers acclimatized to $\mathrm{CIH}$ a poorer sleep quality at $3,800 \mathrm{~m}$ than at sea level was observed. In this study some of the changes observed between sea level and altitude were: greater number of arousals (10.4 vs. 28.7), higher apneas/hypopneas index (5.8 vs. 10.1), and greater oxygen desaturation and periodic breathing (zero vs. 9.8) (Vargas et al., 2002). Supplemental oxygen partially reduced these differences between sea level and high altitude.

There is great concern regarding exposure to altitude of obstructive sleep apnea (OSA) syndrome carriers, since their cyclical reduction in $\% \mathrm{SaO}_{2}$ during sleep is exacerbated by environmental hypobaric hypoxia. $\% \mathrm{SaO}_{2}$ is low during sleep in altitude, and whereas the development of AMS has been shown to be partially associated with low mean $\% \mathrm{SaO}_{2}$ in sleep (Burgess et al., 2004), positive airway pressure has been shown to prevent the occurrence of AMS (Johnson et al., 2010). Thus it is considered that untreated obstructive sleep apnea is a condition incompatible with altitude. In turn, the effects observed, including excessive daytime sleepiness and impaired daytime function, can affect job performance.

In terms of the respiratory mechanisms contributing to AMS, it has been long recognized that the ventilatory response is reduced in people susceptible to AMS (Hackett et al., 1982). Recently, in a group of people exposed to experimental hypoxia $\left(\mathrm{FIO}_{2}=80 \% \mathrm{SaO}_{2}\right)$, the acute hypoxic ventilatory response at $5 \mathrm{~min}$ (HVR5min) was greater in individuals not susceptible to AMS compared to susceptible individuals (Nespoulet et al., 2012). These results support the hypothesis of low chemoreceptor sensitivity as a marker of AMS predisposition (Moore et al., 1986), suggesting high chemo sensitivity as a protective factor for AMS.

\subsection{Oxidative stress}

Reactive oxygen species (ROS) are produced by diverse cellular processes and are considered to have beneficial and harmful effects. Moderate concentrations of ROS mediate their beneficial effects such as cellular defense against infections, control of vascular tone, ventilation and erythropoietin production, the induction of mitogenic responses and modulation of several transduction signaling pathways. Overproduction of ROS leads to their harmful effects due to oxidative stress (for reviews see Dröge, 2002 and Valko et al., 2007).

Several reports indicate that exposure to high altitude hypobaric hypoxia causes oxidative cellular damage. This cellular oxidative stress appears directly related to the altitude level and an increased production of ROS seems to be responsible for these effects (Dosek et al., 2007). Concomitantly, oxygen enrichment of room air is increasingly being used in work stations at high altitude (West, 2002, 2003) and since the production of ROS is favored at higher oxygen supply (Dosek et al., 2007; González et al., 2002), oxidative stress may be an even more important factor in high altitude exposed workers.

The main cause of oxidative stress is the lower availability of $\mathrm{O}_{2}$ to be reduced to $\mathrm{H}_{2} \mathrm{O}$ by the enzyme cytochrome oxidase in the mitochondrial respiratory chain. This produces an accumulation of electrons that in the absence of sufficient oxygen as final acceptor will form superoxide anion $\left(\mathrm{O}_{2}^{-}\right)$ which in turn produces hydrogen peroxide $\left(\mathrm{H}_{2} \mathrm{O}_{2}\right)$ and the 
hydroxyl radical $\left(\mathrm{OH}^{-}\right)$after reacting with water (Maiti et al., 2006). The accumulation of these reduced equivalents formed principally in complexes I and III of the electron transport chain is known as "reductive stress" and can favor selfoxidation of one or more mitochondrial complexes, such as the redox pair ubiquinone-biquinol, as well as increasing the $\mathrm{NADH} / \mathrm{NAD}^{+}$ratio (Dosek et al., 2007). The accumulation of free radicals of coenzyme $Q$, called ubisemiquinone, causes the transfer of its unpaired electron to oxygen, generating the superoxide radical anion $\left(\mathrm{O}_{2}^{-}\right)$. Although $\left(\mathrm{O}_{2}^{-}\right)$by itself is not particularly harmful, it is a precursor of the highly reactive hydroxyl radical $\left(\mathrm{OH}^{-}\right)$and, through irreversible condensation with nitric acid, forms peroxynitrite (ONOO) (Manukhina et al., 2006). Oxidative damage may also be produced by reductions in the antioxidant capacity, and it has been established that during hypoxia the cellular systems of redox defense are affected. Antioxidant enzyme activities such as superoxide dismutase (SOD), glutathione reductase (GSR) and glutathione peroxidase (GPX) are reduced (Maiti et al., 2006). Other molecular events that also favor oxidative stress induced by hypobaric hypoxia are the xanthine dehydrogenase/oxidase system and the inducible isoform of nitric acid synthase (iNOS). The former has been described as a strong ROS generator in high altitude conditions, as hypoxic cells generate greater amounts of ATP and cAMP by the action of adenylyl kinase from two ADP. iNOS is up-regulated during acclimatization, thus altering the balance of ROS/ NO, which recovers as time elapses (Dosek et al., 2007). The alteration in this balance may be related to the microcirculatory changes caused by hypobaric hypoxia expressed in AMS and cerebral and pulmonary edemas (Dosek et al., 2007). Finally, other factors that contribute to the development of oxidative stress are exercise, UV radiation (which penetrates the epidermis with greater aggressiveness in high-altitude zones), lack of antioxidant supplements in the diet and the oxidation of catecholamines (adrenaline, noradrenaline and dopamine), which increases with altitude (Askew, 2002). The high reactivity and oxidant properties characteristic of ROS and free radicals result in overall damage that affects main cell components including carbohydrates, proteins, lipids and even DNA (Blokhina et al., 2003).

Little is known about the level of real oxidative damage suffered by cell structures of the organs and tissues exposed to a situation of high altitude. Moller et al., (2001) exposed 12 healthy individuals to an altitude of $4,559 \mathrm{~m}$, which caused a significant increase in the rupture of the DNA chain measured in the urine. The damage was prominent in endonucleaseIII sites. Also, when a group of humans were exposed simultaneously to an altitude of $2,700 \mathrm{~m}$ and cold conditions, the peroxide lipid levels and the DNA damaged chain in the urine increased up to $23 \%$ at $6,000 \mathrm{~m}$ and up to $79 \%$ at 8,848 $\mathrm{m}$, indicating that the oxidative stress increases with escalating altitude (Joanny et al., 2001). Thus, studies performed on humans consistently describe that high altitude hypoxia causes oxidative damage to lipids, proteins, and DNA chains. This damage may be due to the increase in the production of ROS and/or to the reduced antioxidant capacity. Given their high content in unsaturated fatty acids, cell membranes constitute a main target of ROS, with lipoperoxidation being usually observed upon exposure to hypoxia (Behn et al., 2007). In animal models, CIH (12 hrs per day, simulated 4,000 m altitude for 6 months) increases lipoperoxidation and carbonyl derivatives in skeletal muscle (Radak et al., 1994, 1997). However, short exposure for 5 days to 7,576 m elevation causes an increase in lipoperoxidation in plasma in rats (Kumar et al., 1999). Maiti et al. (2006) also reported that exposure of 3 and 7 days to $6,100 \mathrm{~m}$ significantly increases ROS levels and lipoperoxidation in various brain regions. It appears that the effects of oxidative stress are systemic, as suggested by Nakanishi et al. (1995), who reported that exposure to 5,000 $\mathrm{m}$ resulted in increased serum levels of malonydialdehyde in lungs, liver, heart and kidneys in rats, whereas exposition to a simulated altitude of 9,000 m causes increases in lipid peroxidation of selected rat brain membranes (Rauchová et al., 2012).

As previously stated, exposure to high altitudes reduces activity and expression levels of antioxidant enzymes; consequently the disruption in the efficiency of the antioxidant systems due to the increase in ROS production by hypobaric hypoxia leads to oxidative damage of macromolecules (Dosek et al., 2007). A reduction in the activity of superoxide dismutase (SOD) content in skeletal muscle has been reported in rats exposed to intermittent hypobaric hypoxia (Radak et al., 1994). Reduction in the activity of glutathione peroxidase (GPX) has also been shown in the liver of rats exposed to high altitude (Nakanishi et al., 1995), whereas Imai et al. (1995) compared GPX activity of high altitude residents $(4,000 \mathrm{~m})$ to individuals from sea level, finding that high-altitude dwellers had lower levels of GPX activity. Nevertheless, it has been observed that catalase (CAT), SOD and also the heat shock proteins lead to the stabilization of cell membranes and restriction of apoptosis, alleviating the oxidative effect when subjected to hypobaric hypoxia (Manukhina et al., 2006). Rat myocardia cells, for example, presented high levels of SOD and CAT after $\mathrm{CIH}$ exposure to 3,500 m (Ning et al., 2000). Additionally, our studies of expression and activity of glutathione reductase (GR) in CIH found no differences in GR expression, but lower activity in testes and epididymis in $\mathrm{CIH}$ exposed rats (Farias et al. 2010). However, we observed that melatonin decreased lipid peroxidation in heart, kidneys and lung under $\mathrm{CIH}$ conditions, but melatonin did not exhibit any protective effect in liver, testis, epididymis sperm count (Farias et al., 2012). It is generally accepted that testicular and seminal ROS levels are important in terms of the deleterious effects of hypoxia on male fertility (Reyes et al., 2012).

In view of the pathological roles played by increased ROS generation, the supplementation of antioxidants seems a good detoxification strategy to improve tissue function under hypobaric hypoxia. In our rat model we observed that exogenous administration of ascorbic acid and blueberry extract restored GR activity, reduced lipoperoxidation and hypospermatogenesis typical of hypobaric hypoxic exposure (Farias et al., 2010; Zepeda et al., 2012). However, the clinical translation of antioxidant therapies has proven difficult, as few benefits and even harmful effects (Dotan et al., 2009) have been observed in clinical trials aimed to reduce oxidative stress by antioxidant supplementation (Armitage et al., 2009; Villanueva and Kross, 2012).

\section{FINAL CONSIDERATIONS}

Exposure to chronic and intermittent hypobaric hypoxia is a biomedical condition unique in the world and represents a great challenge for miners such as Chilean mine workers. 
Studies leading to the elaboration of strategies to prevent and revert the negative physiological effects brought about by exposure to high altitudes are highly desirable. Specifically, urgent new challenges for the future are: a) Acute Mountain Sickness on the first day of the re-ascent after 3-7 days of rest; this condition affects people with signs of good acclimatization, oxygen saturation, without polycythemia or hypertension, despite years of exposure to $\mathrm{CIH}, \mathrm{b})$ Prevention or control of disturbance of quality of sleep, periodic breathing, oxygen desaturation, sleep fragmentation and / or total sleep, c) Causes of polycythemia in $\mathrm{CIH}, \mathrm{d}$ ) Biological parameters that define a suitable physiological intermittent hypoxia acclimatization to altitudes between 3,000 and 5,500 m, e) Long-term monitoring of pulmonary artery pressure, f) Aging biomarkers of $\mathrm{CIH}$, g) Hypoxia tolerance test to identify, at sea level, before the climb, the good responders to hypoxia and susceptibility to severe AMS, and h) Best strategies to mitigate the effects of $\mathrm{CIH}$, based on nutrients, sleep hygiene, supplemental oxygenation, commuting patterns, ergonomic jobs adjustments, etc. The determination of markers that can identify in advance the good and bad responders to this environmental condition (Richalet et al., 2012; Burtscher et al., 2008), as well as markers of health condition of workers chronically exposed will greatly contribute to the health of miners who have to work intermittently under different shift schemes at work sites over $4,000 \mathrm{~m}$ altitude. in the Andes mountain range.

\section{ACKNOWLEDGEMENTS}

The authors are sincerely thankful for the support provided by DIUFRO grant DI12-2007 and CONICYT PhD Fellowship Program.

\section{REFERENCES}

AMERICAN COLLEGE OF SPORTS MEDICINE (2000) ACSM's guidelines for exercise testing and prescription. 6:145.

ANHOLM JD, POWLES AC, DOWNEY R, 3RD, HOUSTON CS, SUTTON JR, BONNET MH, et al. (1992) Operation Everest II: arterial oxygen saturation and sleep at extreme simulated altitude. Am Rev Respir Dis 145(4 Pt 1):817-826.

ANTEZANA AM (2003) Cardiovascular changes in chronic intermittent hypoxia. In Health \& Height, Viscor G, Ricart A, Leal C, edit Publicacions Universitat Barcelona, pp151-155

ASKEW E (2002) Work at high altitude and oxidative stress: antioxidants nutrients. Toxicology 180(2):107-119.

ARANEDA O, GARCÍA C, LAGOS N, QUIROGA G, CAJIGAL J, SALAZAR MP, BEHN C (2005) Lung oxidative stress as related to exercise and altitude. Lipid peroxidation evidence in exhaled breath condensate: a possible predictor of acute mountain sickness Eur J Appl Physiol. 95:383-390.

ARMITAGE ME, WINGLER K, SCHMIDT HH, LA M.(2009) Translating the oxidative stress hypothesis into the clinic: NOX versus NOS. J Mol Med (Berl). 87(11):1071-1076.

BASUALTO-ALARCÓN C, RODAS G, GALILEA P, RIERA J, PAGÉS T, RICARTE A, TORRELlA J, BEHN C, VISCOR G (2012) Cardiorespiratory parameters during submaximal exercise under acute exposure to normobaric and hypobaric hypoxia. Apunts Med Esport. $47(174): 65-72$

BEGUIN PC, BELAIDI E, GODIN-RIBUOT D, LEVY P, RIBUOT C (2007) Intermittent hypoxia-induced delayed cardioprotection is mediated by PKC and triggered by p38 MAP kinase and Erk1/2. J Mol Cell Cardiol 42: 343-351.

BEHN C, ARANEDA OF, LLANOS AJ, CELEDÓN G, GONZÁLEZ G (2007) Hypoxia-related lipid peroxidation: evidences, implications and approaches. Respir Physiol Neurobiol 158:143-150.
BLOKHINA O, VIROLAINEN E, FAGERSTEDT K (2003) Antioxidants, oxidative damage and oxygen deprivation stress: a review. Ann Bot 91(2):179-194.

BRITO J, SIQUES P, LEÓN-VELARDE F, DE LA CRUZ JJ, LOPEZ V, HERRUZO R (2007) Chronic intermittent hypoxia at high altitude exposure for over 12 years: assessment of hematological cardiovascular, and renal effects. High Alt Med Biol 8(3):236-244.

BROOKS D, HORNER RL, KOZAR LF, RENDER-TEIXEIRA CL, PHILLIPSON EA (1997) Obstructive sleep apnea as a cause of systemic hypertension. Evidence from a canine model. J Clin Invest 99:106-109.

BUSTOS-OBREGÓN E, RIVEROS J, MAURER I (2005) Función espermática post-hipoxia simulada en ratón. Cienc Trab 7(16):56-60.

BROOKS GA, BUTTERFIELD GE, WOLFE RR, GROVES BM, MAZZEO RS, SUTTON JR, WOLFEL EE, REEVES JT (1991) Increased dependence on blood glucose after acclimatization to 4,300 m. J Appl Physiol 70:919-927.

BURTSCHER M, SZUBSKI C, FAULHABER M (2008) Prediction of the susceptibility to AMS in simulated altitude. Sleep Breath. 12(2):103-108.

CASANEGRA P, JALIL J, BRAUN S, CHAMORRO G, RODRÍGUEZ R, ILIC JP, MORALES M, LISBOA C, SALDIAS F, BEROIZA T (1993) Periodic physical work at high altitude mining: long term evaluation of exercise responses under one specific working cycle. In: Hypoxia and Molecular Medicine. Sutton J, Houston C, Coates G, editors. Queen City Printers Inc. Vermont, USA, pp 296.

CHAMORRO G, BRAUN S, JALIL J, ILIC JP, BEROIZA T, CASANEGRA P, RODRÍGUEZ R (1993) High altitude mining: influence of working cycle on changes in pulmonary pressure. In: Hypoxia and Molecular Medicine. Sutton J, Houston C, Coates G, eds. Queen City Printers Inc. Vermont, USA, pp 296.

COSTILL DL, COYLE E, DALSKY G, EVANS W, FINK W, HOOPES D (1977) Effects of elevated plasma FFA and insulin on muscle glycogen usage during exercise. J Appl Physiol 43:695-699.

CORNOLO J, MOLLARD P, BRUGNIAUX JV, ROBACH P, RICHALET JP (2004) Autonomic control of the cardiovascular system during acclimatization to high altitude: effects of sildenafil. J Appl Physiol 97: 935-940.

DE PAULA P, NIEBAUER J (2012) Effects of high altitude training on exercise capacity: fact or myth. Sleep Breath 16(1):233-239.

DONG JW, ZHU HF, ZHU WZ, DING HL, MA TM, ZHOU ZN (2003) Intermittent hypoxia attenuates ischemia/reperfusion induced apoptosis in cardiac myocytes. Cell Res 13:385-391.

DOSEK A, OHNOB H, ACSA Z, TAYLOR A, RADAK Z (2007) High altitude and oxidative stress Respir Physiol Neurobiol 158:128-131.

DOTAN Y, PINCHUK I, LICHTENBERG D, LESHNO M (2009) Decision analysis supports the paradigm that indiscriminate supplementation of vitamin E does more harm than good. Arterioscler Thromb Vasc Biol 29:1304-1309.

ECKARDT KU, BOUTELLIER U, KURTZ A, SCHOPEN M, KOLLER EA, BAUER W (1989) Rate of erythropoietin in humans in response to acute hypobaric hypoxia. J Appl Physiol. 6(4):1785-1788.

FARÍAS JG, BUSTOS-OBREGON E, ORELLANA R, BUCAREY, JL, QUIROZ E, REYES JG (2005a) Effects of chronic hypobaric hypoxia on testis histology and round spermatid oxidative metabolism. Andrologia 37:4752.

FARÍAS JG, BUSTOS-OBREGÓN R, REYES J (2005b). Increase in testicular tTemperature and vascularization induced by hypobaric hypoxia in rats. J Androl 26(6):693-697.

FARÍAS JG, OSORIO J, SOTO G, BRITO J, SIQUÉS P, REYES J (2006). Sustained acclimatization in Chilean mine workers subjected to chronic intermittent hypoxia. High Alt Med Biol 7(4):302-306.

FARÍAS JG, PUEBLA M, ACEVEDO A, TAPIA P, GUTIERREZ E, ZEPEDA A, CALAF G, JUANTOK C, REYES, J (2010) Oxidative stress in testis and epididymis under intermittent hypobaric hypoxia in rats: protective role of antioxidant supplementation. J Androl 31(3):314-321.

FARÍAS JG, ZEPEDA AB, CALAF G (2012) Melatonin protects the heart, lungs and kidneys from oxidative stress under intermittent hypobaric hypoxia in rats. Biol Res 45:81-85.

FLETCHER EC, LESSKE J, QIAN W, MILLER CC, 3RD, UNGER T (1992, Repetitive, episodic hypoxia causes diurnal elevation of blood pressure in rats. Hypertension 19:555-561.

FORGEY WW (2006). High-altitude illness. In: Wilderness Medical Society: Practice Guidelines for Wilderness Emergency Care. W. W. Forgey, ed. Guilford, New York; pp. 46-53.

FULCO CS, ROCK PB, AND CYMERMAN (2000) Improving athletic performance: is altitude residence or altitude training helpful? Aviat Space Environ Med 71:162-171. 
GAMBOA R (2003) Circulación Sistémica. in "El Resto Fisiológico de vivir en los Andes". Monge C, León-Velarde F, Eds. IFEA UPCH. Lima. Peru. 2003. pp. 119-132.

GILMARTIN GS, TAMISIER R, CURLEY M, WEISS JW (2008) Ventilatory, hemodynamic, sympathetic nervous system, and vascular reactivity changes after recurrent nocturnal sustained hypoxia in humans. Am J Physiol Heart Circ Physiol 295(2):H778-H785.

GONZÁLEZ C, SANZ-ALFAYATE G, AGAPITO T, GÓMEZ-NIÑO A ROCHER A AND OBESO A (2002) Significance of ROS in oxygen sensing in cell systems with sensitivity to physiological hypoxia. Respir Physiol Neurobiol. 132(1):17-41

GUAN Y, GAO L, MA H, LI Q, ZHANG H, YUAN F, ZHOU Z, ZHANG Y (2010) Chronic intermittent hypobaric hypoxia decreases-adrenoceptor activity in right ventricular papillary muscle. Am J Physiol Heart Circ Physiol. 298:H1267-H1272.

HACKETT PH, RENNIE D, HOFMEISTER SE, GROVER RF, GROVER EB, REEVES JT (1982) Fluid retention and relative hypoventilation in acute mountain sickness. Respiration 43(5):321-9.

HACKETT PH, RENNIE ID, LEVINE HD (1976) The incidence, importance, and prophylaxis of acute mountain sickness. Lancet 2(7996):1149-1154.

HULTGREN H (1997) High Altitude Medicine. H.N. Hultgren pub., San Francisco, USA, pp. 68-69.

HURTADO A (1960) Some clinical aspects of life at high altitudes. Ann Intern Med. 53:247-258.

IMAI H, KASHIWAZAKI H, SUZUKI T, KABUTO M, HIMENO S, WATANABE C, MOJI K, KIM SW, RIVERA JO, TAKEMOTO T (1995) Selenium levels and glutathione peroxidase activities in blood in an andean high-altitude population. J Nutr Sci Vitaminol (Tokyo) 41:349361.

JALIL J, BRAUN S, CHAMORRO G, CASANEGRA P, SALDÍAS F, BEROÍZA T, FORADORI A, RODRÍGUEZ R, MORALES M (1994) Cardiovascular response to exercise at high altitude in workers chronically exposed to intermittent hypobaric hypoxia. Rev Med Chil. 122(10):1120-1125.

JIMÉNEZ D (1995) High altitude intermittent chronic exposure to hypoxia. In Hypoxia and the Brain. Sutton JR, Houston CS, Coates G, eds Burlington, Vt, USA. p. 284-291.

JIMÉNEZ D (2003) Mountain medicine for sustainable high altitude mining. In: Health Environment and Sustainable Development, Copper 2003. Lagos G, Warner A, Sanchez M, eds. MetSoc, Quebec, Canada. Vol 2:459468.

JOANNY P, STEINBERG J, ROBACH P, RICHALET JP, GORTAN C, GARDETTE B, JAMMES Y (2001). Operation Everest III (Comex'97): the effect of simulated sever hypobaric hypoxia on lipid peroxidation and antioxidant defence systems in human blood at rest and after maximal exercise. Resuscitation 49:307-314.

KENNEDY SL, STANLEY WC, PANCHAL AR, MAZZEO RS (2001) Alterations in enzymes involved in fat metabolism after acute and chronic altitude exposure. J Appl Physiol 90:17-22.

KUMAR D, BANSAL A, THOMAS P, SAIRAM M, SHARMA S, MONGIA S, SINGH S, SELVAMURTHY S (1999). Biochemical and immunological changes on oral glutamate feeding in male albino rats. Int J Biometeorol. 42:201-204.

LEÓN-VELARDE F, MAGGIORINI M, REEVES JT, ALDASHEV A, ASMUS I, BERNARDI L, GE RL, HACKETT P, KOBAYASHI T, MOORE LG, PENALOZA D, RICHALET JP, ROACH R, WU T, VARGAS E, ZUBIETACASTILLO G AND ZUBIETA-CALLEJA G (2005) Consensus statement on chronic and subacute high altitude diseases. High Alt Med Biol. 6(2):147-1157

LEÓN-VELARDE F, VILLAFUERTE FC, RICHALET JP (2010) Chronic mountain sickness and the heart. Prog Cardiovasc Dis. 52(6):540-9.

MAITI P, SINGH S, SHARMA A, MUTHURAJU S, BANERJEE P AND ILAVAZHAGAN G (2006) Hypobaric hypoxia induces oxidative stress in rat brain. Neurochem Int. 49(8):709-716.

MCLAUGHLIN VV, RICH S (2004) Pulmonary hypertension. Curr Probl Cardiol. 29(10):575-634.

MEERSON FZ, MALYSHEV IYU, ZAMOTINSKY AV (1992). Differences in adaptive stabilization of structures in response to stress and hypoxia relate with the accumulation of hsp70 isoforms. Mol Cell Biochem. 111: 87-95.

MILLET GP, ROELS B, SCHMITT L, WOORONS X, RICHALET JP (2010) Combining hypoxic methods for peak performance. Sports Med. 40(1):125.

MOLLER P, LOFT S, LUNDBY C, OLSEN N (2001) Acute hypoxia and hypoxic exercise induce DNA strand breaks and oxidative DNA damage in humans. FASEB J. 15(7):1181-1186
MOORE LG, HARRISON GL, MCCULLOUGH RE, MCCULLOUGH RG, MICCO AJ, TUCKER A, WEIL JV, REEVES JT (1986) Low acute hypoxic ventilatory response and hypoxic depression in acute altitude sickness. J Appl Physiol. 60(4):1407-12.

MORTIMER EA JR, MONSON RR, MACMAHON B (1977) Reduction in mortality from coronary heart disease in men residing at high altitude. N Engl J Med. 296(11):581-5.

NAEIJE R (2010) Physiological adaptations of the cardiovascular system to high altitude. Prog Cardiovasc Dis. 52:456-466.

NAKANISHI K, TAJIMA F, NAKAMURA A, YAGURA S, OOKAWARA T, YAMASHITA H, SUZUKI K, TANIGUCHI N, OHNO H (1995) Antioxidant system in hypobaric-hypoxia in rats. J Physiol. 489:869-876.

NESPOULET H, WUYAM B, TAMISIER R, SAUNIER C, MONNERET D, REMY J, CHABRE O, PÉPIN JL, LÉVY P (2012) Altitude illness is related to low hypoxic chemoresponse and low oxygenation during sleep. Eur Respir J. 40(3):673-80.

NING Z, YI Z, QI-ZHI F, ZHAO-NIAN Z (2000) Intermittent hypoxia exposure-induced heat-shock protein 70 expression increases resistance of rat heart to ischemic injury. Acta Pharmacol Sin. 21(5):467-472.

PASHA MA AND NEWMAN JH (2010). High-altitude disorders: pulmonary hypertension: pulmonary vascular disease: the global perspective. Chest 137(6 Suppl):13S-19S.

PEŇALOZA D AND ARIAS-STELLA J (2007) The heart and pulmonary circulation at high altitudes. Healthy highlanders and Chronic Mountain Sickness. Circulation 115:1132-1146.

PEPPARD PE, YOUNG T, PALTA M, SKATRUD J (2002) Prospective study of the association between sleep-disordered breathing and hypertension. $\mathrm{N}$ Engl J Med 342:1378-1384.

PRABHAKAR NR (2000) Oxygen sensing in the carotid body chemoreceptors. J Appl Physiol 88: 2287-2295.

PRZYBYLOWSKI T, ASHIRBAEV A, LE ROUX J, ZIELIŃSKI J (2003) Sleep and breathing at altitude of $3800 \mathrm{~m}$-the acclimatization effect. Pneumonol Alergol Pol 71(5-6):213-220.

RADAK Z, LEE K, CHOI W, SUNOO S, KIZAKI T, OH-ISHI S, SUZUKI K, TANIGUCHI N, OHNO H, ASANO K (1994). Oxidative stress induced by intermittent exposure at a simulated altitude of $4000 \mathrm{~m}$ decreases mitochondrial superoxide dismutase content in soleus muscle of rats. Eur J Appl Physiol Occup Physiol 69:392-395.

RADAK Z, ASANO K, LEE KC, OHNO H, NAKAMURA A, NAKAMOTO H, GOTO S (1997) High altitude training increases reactive carbonyl derivatives but not lipid peroxidation in skeletal muscle of rats. Free Radic Biol Med 22:1109-1114.

RAUCHOVÁ M, VOKURKOVÁ J, KOUDELOVÁ J (2012) Hypoxia-induced lipid peroxidation in the brain during postnatal ontogenesis. Physiol Res. 61 (Suppl. 1): S89-S101.

RENNIE JJ AND HOLLOSZY JO (1977) Inhibition of glucose uptake and glycogenolysis by availability of oleate in well oxygenated perfused skeletal muscle. Biochem J 168:161-170.

REYES JG, FARÍAS JG, HENRIQUEZ-OLAVARRIETA S, MADRID E, PARRAGA M, ZEPEDA AB, MORENO RD (2012) The hypoxic testicle: physiology and pathophysiology. Oxid Med Cell Longev, vol. 2012, Article ID 929285, 15 pages. doi:10.1155/2012/929285

RICHALET JP (1990) The heart and adrenergic system in hypoxia. In: Hypoxia: The Adaptations. Edited by J.R. Sutton, G. Coates, and J.E. Remmers. Toronto, Philadelphia: B.C. Decker Inc., p. 13-21

RICHALET JP, KACIMI R, ANTEZANA AM (1992) The control of chronotropic function in hypobaric hypoxia. Int J Sports Med 13:S22S24.

RICHALET JP, LARMIGNAT P, POITRINE E, LETOURNEL M, CANOUÏPOITRINE F (2012) Physiological risk factors for severe high-altitude illness: a prospective cohort study. Am J Respir Crit Care Med 185(2):192-198.

RICHALET JP, VARGAS M, JIMÉNEZ D, ANTEZANA AM, HUDSON C, CORTÉS G, OSORIO J, LEÓN G (2002) Chilean miners commuting from sea level to $4500 \mathrm{~m}$ : A prospective study. High Alt Med Biol 3:159-166.

SARYBAEV A, PALASIEWICZ G, USUPBAEVA D, PLYWACZEWSKI R, MARIPOV A, SYDYKOV A, MIRRAKHIMOV M, LE ROUX $\mathrm{H}$, KADYROV T, ZIELINSKI J (2003) Effects of intermittent exposure to high altitude on pulmonary hemodynamics: a prospective study. High Alt Med Biol 4 (4):455-463.

SEVRE K, BENDZ B, HANKO E, NAKSTAD AR, HAUGE A, KÅSIN JI, LEFRANDT JD, SMIT AJ, EIDE I, ROSTRUP M (2001) Reduced autonomic activity during stepwise exposure to high altitude. Acta Physiol Scand 173(4):409-17.

SCHOFIELD C. AND RATCLIFFE P (2004) Oxygen sensing by HIF hidrolases. Nat Rev Mol Cell Biol. 5: 343-354. 
SKINNER IS, GASKILL SE, RANKINEN T, LEÓN AS, RAO DC, WILMORE JH, BOUCHARD C (2003) Heart rate versus \% $\mathrm{VO}_{2}$ max: age, sex, race, initial fitness, and training response-HERITAGE. Med Sci Sports Exerc. 35(11):1908-1913.

TAMISIER R, GILMARTIN G, LAUNOIS S, PÉPIN J, NESPOULET $\mathrm{H}$, THOMAS R, LÉVY P, AND WEISS J (2009) A new model of chronic intermittent hypoxia in humans: effect on ventilation, sleep, and blood pressure. J Appl Physiol. 107(1):17-24.

VARGAS E. VILLENA M (1989) La vie humaine en haute altitude: mythes et realités. Bull Soc Pathol Exot Filiales 82(5):701-19.

VALENCIA-FLORES M, REBOLLAR V, SANTIAGO V, OREA A, RODRÍGUEZ C, RESENDIZ M (2004). Prevalence of pulmonary hypertension and its association with respiratory disturbances in obese patients living at moderately high altitude. Int J Obes Relat Metab Disord 28:1174- 1180 .

VALKO M, LEIBFRITZ D, MONCOL J, CRONIN MT, MAZUR M, TELSER J (2007) Free radicals and antioxidants in normal physiological functions and human disease. Int J Biochem Cell Biol. 39(1):44-84.

VEARRIER D AND GREENBERG MI (2011) Occupational health of miners at altitude: adverse health effects, toxic exposures, pre-placement screening, acclimatization, and worker surveillance. Clin Toxicol (Phila) 49(7):629-640

VILLANUEVA C, KROSS RD (2012) Antioxidant-induced stress. Int J Mol Sci. 13:2091-2109.

VOGT M, HOPPELER H (2010) Is hypoxia training good for muscles and exercise performance?. Prog Cardiovasc Dis 52(6):525-33.

VARGAS M, LASSO J, RIVEROS A, HUDSON C, JIMÉNEZ D (2002) Polysomnography in acclimatized workers to intermittent hypoxia, comparison of sea level, altitude $3,800 \mathrm{~m}$ and oxygen supplementary effect. High Alt Med Biol 3(1):97-137
WEST JB (2002) Commuting to high altitude: value of oxygen enrichment of room air. High Alt Med Biol 2:223-235.

WEST JB (2003) Improving oxygenation at high altitude: acclimatization and $\mathrm{O}_{2}$ enrichment. High Alt Med Biol 4:389-398.

WEST JB, SCHOENE R, MILLEDGE J (2007) High Altitude Medicine and Physiology. Hodder Arnold. pag 39,40.

WILBER RL (2007) Application of altitude/hypoxic training by elite athletes. Med Sci Sports Exerc. 39 (9):1610-1624.

YOUNG A J, EVANS WJ, CYMERMAN A, PANDOLF KB, KNAPIK JJ, MAHER JT (1982) Sparing effect of chronic high altitude exposure on muscle glycogen utilization during exercise. J Appl Physiol 52:857-862.

ZEPEDA A, AGUAYO LG, FUENTEALBA J, et al (2012) Blueberry extracts protect testis from hypobaric hypoxia induced oxidative stress in rats. Oxid Med Cell Longev (2012) Article ID 975870, 7 pages, doi:10.1155/2012/975870

ZHANG Y, ZHONG N, GIA J, ZHOU Z (2004) Effects of chronic intermittent hypoxia on the hemodynamics of systemic circulation in rats. Jpn J Physiol 54:171-174.

ZHONG N, ZHANG Y, ZHU HF, WANG JC, FANG QZ, ZHOU ZN (2002) Myocardial capillary angiogenesis and coronary flow in ischemia tolerance rat by adaptation to intermittent high altitude hypoxia. Acta Pharmacol Sin 23:305-310.

ZHU HF, DONG JW, ZHU WZ, DING HL, ZHOU ZN (2003) ATP-dependent potassium channels involved in the cardiac protection induced by intermittent hypoxia against ischemia/reperfusion injury. Life Sci 73:1275-1287.

ZHU WZ, XIE Y, CHEN L, YANG HT, ZHOU ZN (2006) Intermittent high altitude hypoxia inhibits opening of mitochondrial permeability transition pores against reperfusion injury. J Mol Cell Cardiol 40:96-106. 
